\title{
Gender in Asian Movie: Narrative Deconstruction Analysis of Rashomon
}

\author{
Rina Sari Kusuma \\ Universitas Mubammadiyah Surakarta, Jl. A. Yani Pabelan Kartasura Tromol Pos 1, Surakarta, Indonesia, \\ 082220091449,Rinasari.Kusuma@ums.ac.id
}

\begin{abstract}
Movie, as a means of mass communication, narrating life in a set of binary - that have different privilege. This research wants to examine movie entitled Rashomon, directed by Akira Kurosawa in 1950, in narrating gender as one of characters code that gave diverse contradictive testimonies about the same events; rape and murder. Rashomon used multiple narrators that build the same story from different point of view that lead to the subjectivity and relativity of truth which the director didn't give the audience clue how to interpret it. The characters that consist of one women and six men give us a glimpse of sign that there is no gender neutrality will be found in this movie, just like what feminist narratologist saying. With deconstructive approach, this research wants to traces the micro-power of textual process, exposing centralizing and unravelling aspects, making less visible aspects more apparent about gender in movie. Deconstructive reading of Rashomon will generating new discourse about binary opposition men/women by questioning masculinity.
\end{abstract}

Keywords: Movie, Gender, Narrative, Deconstruction, Rashomon

\section{Introduction}

Human, God creature who always try to show their utopia side of themselves, becomes never ending object to talk about. How human actually faced with two opposite poles, truth and lie. The searching for meaning of life occasionaly directed to one concept that considered absolute, the truth.

We are narrative creature that understands life as a set of ongoing narrative, a conflict, character, beginning, middle, and ending. Fisher (1987) says that every human communication is a story. Telling and analysis of narratives are human activities that necessarily entail gendered assumptions and practices.

Gender refers to the different sets of social and cultural characteristics, but falsely thought to be inherent to each sex as a result of natural biological or natural reproductive difference. Media provide an extremely limited range of resources which promote limited and biased conceptualisations of women. Media becomes one source constantly deliver messages about gender assumption, turn to stereotype. Many scholars note stereotyping is reproduced in our society with the help of mass media. Browne, Mickiewicz, dan Firestone (Tyree, 2011) asserted mass media are suitable to pass along stereotypes, "because they extend throughout society and frequently serve as trend-setters, taste-makes, labelers, and the raw material for daily conversation".

Narrative theory is a flexible tool, useful for analyzing elements of storytelling common across a wide range of media. Although we must be aware of the ways any specific medium create particular storytelling parameter. Narrative movie privileged tha frame of the diegesis, Greek word for story: it fosters, 
during our viewing experience, the apprehension of a single, consistent, integral imagined world, in which actions connect with one another casually, through which, generally, one central character makes his or her way from an initial state to a different, final state (Fulton, 2005).

Movie is a game. A game looking for an answer of question asked earlier, assembling the puzzle intact. Model that Noel Carrol called Erotetic model of narrative, model of asking and answering which the next scene answering question that happened previously, though Rashomon might not fit that definition. The answer we expect to get at the end of the movie results in nothing. Rashomon frustrates us when it fails to adequately disclose the originary crime - rape and murder - the status of the crime (Lofgren, 2015).

Rashomon was released a mere 4 years after the Japanese government promulgated a constitutional revision, Article 14 of which ostensibly guarantess equal right for all citizen (Lofgren 2015). Article 14 dictates that "all of the people are equal under the law and there shall be no discrimination in political, economy, or social relations because of racem creed, sex, social status or family origin. So, not surpisingly if the struggle for those right for women is on display in Rashomon.

Feminist narratology is the umbrella term which covers the many different ways in which gender-related aspects of narratives and the models used to analyze them may be interrogated from a feminist point of view (Herman, 2007). It study the narrative structure and strategies in the context of cultural construction of gender. This construction is significant because narrative analysis does not take place in a context-free vacuum. Despite the claim about netraulity in narratological model, in fact it focusing primarily on text by and about men.

Feminist narratology is a result of what has come to be known as second-wave feminism, which began in the West in the 1960s, that demands equal treatment for women and men. This academic application of this within narratology tended to emphasize binary categories and assume patterns of differences between "men" and "women" and the stories they might tell.

Akira Kurosawa's (1950) Rashomon is frequently understood as an exploration of truth in the face of four irreconciably conflicting testimonies (Lofgren, 2015), the rape of the wife and the murder of the husband (the samurai). Testimonies in a court room was told by the bandit (Tajomaru), the wife (Masago), the (Spirit) of the husband (Takehiro), and the woodcutter, unseen witnes that seen the whole scene when he pass them in the wood.

They recount for different versions of these crimes, the bandit claims that he killed the husband in a sword fight after the wife demanded the two duel to save her from dishonour. This story being supported by woodcutter who describe fight to death between them, though with very different details. The wife confesses to murdering her husband with a dagger after he spurned her following the rape, while the husband's account concludes with his ritual suicide after the departure of of the bandit and the wife (Redfern, 2014). The source of the distortion in the different narratives is attributed to the egotism that drives the participants to present the version of events that portrays themselves in the best possible light, and though none can be said to be lying each shapes the facts to fit their character and situation.

From the testimonies itself, we can see that, dominantly, the story od Rashomon is being told by men and more than half of it is about men, Tajomaru and Takehiro. Masago as a rape victim became the minority, not only for the story (portion) about her but also the fact that she was the only women tell the side of the story, in which her testimony totally contradicted with the men's.

When structuralist studies of narrative focused on the text as an object of the study, the 
post-struturalist paid explicit attention to the subject, human being doing the producing or interpreting the narrative (Fulton, 2005). The different summaries of the same narrative will be produces by people with different convension, habits and models of summarising. Even given the same convention, their summaries will be different if the motives and purposes of their summarising are different. People would simplify the narrative at different level of abstraction, and each of them would preserve, omit, link, isolate, and foreground different feature in accordance with particular purpose.

Post structuralist suggest that reader/ audience is the one that have supreme control over the interpretation of what they are reading. Like what Barthes saying, the death of the author, so there will be just multiple layers and meaning, no single truth, of reading. The contradictary testimonies that lead to subjectivity and relativity of perspective in which the writer did not give a clue how to interpret it is a sign that Rashomon did not want to be "read" in singular meaning.

Deconstruction is used to mark the philosophical meaning that deal with how meaning being constructed and understood. Deconstruction is an effort to find the marginal text that serve, reveal, disassemble that can be make sure using positive marking tool, reinterpret the hierarchy, deconstruct to reconstruct what already written (Sarup, 2011).

Gender construction shape by culture and dogmatized by the media to be considered as a center of truth. This is what Derrida believe in deconstruction, how that text being played until the center of narration became unclear text being reconstructed and deconstructed with constracting center. Deconstruction can heighten researcher sensitivity to the political and cultural messages concealed under the surface of persuasions to consume (Stern, 1996). It leads to better understanding of the openness of meaning influenced by a shifting network of language, power, and culture.

Deconstruction involves ways of reading that decentre or unmask narratives that posit authoritative ideas. A deconstructive reading of narrative traces the hierarchy on the opposition between a dominating and a marginalized or subordinated binary term. Deconstructive analysis exposes the "metaphorical colonisations having to do with region, class, race and gender" (Shohat and Stam in Stern, 1996).

The purpose of the study is to reveal how the gender operates as a determinating factor that affect the construction of narrative in Rashomon. Deconstruction being used because its value lies in the power to strip away placid surfaces and reveal the subversion, suppression, and hierarchical power struggles that bubble underneath. Skepticism about a single "right" interpretation arises when one pulls apart binary oppositions to reveal the privileging of the dominant term, man, at the expense of the repressed one, women.

\section{Method}

This study using post-structuralist perspective, which paid the attention to the alternative reading of Rashomon. Post structuralist aware of the perspective, the subjectivity of any interpretation. Deconstruction being used to reveal ideological assumptions in a way that is particularly sensitive to the surpressed interests of members of disempowered, marginalized group (Boje, 2001).

For the purpose of the analysis, we used DVD of Rashomon (1950) from Criterion Collection with English subtitile. The movie last in 88 minutes which still in black and white (BW) color format. Based on screenplay made by Akira Kurosawa and Shinobu Hashimoto, Rashomon had 405 scenes. But analysis only focus on the scenes that show the testimonies of the rape and murder - from four witnesses 
(Tajomaru, Takehiro, Masago, and the Woodcutter).

Though deconstruction is not a formulamethod with steps and certain procedure, Boje (2001) outline eight analytic moves to deconstruct story. The moves include: (1) Duality search, (2) Reinterpret the hierarchy, (3) Rebel voices, (4) Other side of the story, (5) Deny the plot, (6) Find the Exception, (7) State what is between the line, and (8) Resituate. Not all the moves will be used in the analysis. Depends on the text, moves number 3-8 are the choices or alternatives to uncover the hidden ideologies.
First, we search the duality of the story as an effort of freeing the stories from narrative imprisonment. Then, we try to find and resituate the hierarchy of the duality to neutralizing the position between man and women. At last, we apply each moves number 3-8 to the text and see which move is able to discovering the silent voice and what between the lines that did't dominate and try to be hidden in the text.

\section{Result and Discussion}

To make less confusing between testimonies, timeline of the scenes among the witnesses will be presented as below;

Table 1. Testimonies Timeline

\begin{tabular}{|c|c|c|c|c|c|c|c|c|c|}
\hline \multirow[t]{2}{*}{ No } & \multirow[t]{2}{*}{ Witnes } & \multicolumn{8}{|c|}{ Timeline } \\
\hline & & 1 & 2 & 3 & 4 & 5 & 6 & 7 & 8 \\
\hline 1 & Buddhist Monk & & & & & & & & \\
\hline 2 & Tajomaru (the Bandit) & & & & & & & & \\
\hline 3 & Masago (Wife) & & & & & & & & \\
\hline 4 & Takehiro (Husband/ Samurai) & & & & & & & & \\
\hline 5 & Woodcutter (1st Version) & & & & & & & & \\
\hline 6 & Woodcutter (2nd Version) & & & & & & & & \\
\hline 7 & Policeman & & & & & & & & \\
\hline
\end{tabular}

\section{Description:}

1. Passing across the street with Masago and Takehiro

2. Masago and Takehiro's encounter with Tajomaru

3. Tajomaru rape Masago

4. After raping
5. Conflict between Tajomaru, Masago, and Takehiro

6. Takehiro's murder scene/ suicide

7. After the conflict dismissed

8. Tajomaru being captured and arrested by Policeman 
From above timeline, we can conclude that not all testimonies witnessing the crime raping and murder. Only testimonies from Tajomaru, Masago, Takehiro, and Woodcutter that clearly describe about the main event.

\subsection{Masculine/ Feminine, Men/Women Binary}

Every story are told in a way that seek centre and proliferate binary opposites: man/ women, masculinity/ femininity. The purpose of looking this binary is to know how the dualizing concept being played the differences, priveledging the marginal over the dominant.

Binary is a concept that came from Claude Levi-Strauss that usefull in identifying structure that works in text. Binary opposition is a set of concept that deal with contradictory meaning. In structuralism, binary opposisition being seen as a basic controller of philosophy, culture, and language. Saussure saw binary as unit that defined against each other. In post structuralism, binary seen as two-constrasting concept that assumes dominating role over the other (Lacey, 2000).

Life shows humanity divided between two class of individual which is clothes, face, body, way of walking, smiling, and occupation that manifestated differently (Beauvior, 1953). Man and women is binary set that it's disputation about equality never come to an end. Called by St. Thomas as imperfect man, for Aristoteles women being seen of having no certain quality that being had by man.

Different from sexuality, gender is a cultural and social construction. Traditionally, gender being divided into masculine and feminine. Gender expression usually stereotypical, construct by media and society.

Tajomaru and Takehiro mark the masculinity side of men. Characteristics like pride, ambitious, aggresive, competitive, and strong tend to be logic and physically oriented. Scenes like Tajomaru had sword fighting with Takehiro to snatch Masago from him are find in all testimonies.

Femininity is not necessarily seen as the state of "being a women"; instead, it's perceived as a stereotype of woman's role from the past (Gauntlett, 2002), and that's the way Masago being presented in the movie. Emotional, graceful, innocent, weak, and deceitful become characterics that construct the Masago in all men's story but not with Masago side of story.

The binary opposition that Rashomon show is masculinity/ femininity among men/ women. By finding this duality we can reveal the propaganda veil that drive the construction of Rashomon's narrative. Below are the list of characteristic that found in the movie: 
Table 2. Gender Characteristics in Rashomon

\begin{tabular}{|c|c|c|c|c|c|}
\hline \multirow{2}{*}{\multicolumn{2}{|c|}{ Character }} & \multicolumn{4}{|c|}{ Testimonies by } \\
\hline & & \multirow{2}{*}{$\frac{\text { Tajomaru }}{\mathrm{X}}$} & \multirow[t]{2}{*}{ Masago } & \multirow[t]{2}{*}{ Takehiro } & \multirow[t]{2}{*}{ Woodcutter } \\
\hline \multirow{5}{*}{ Masculine } & Ambisious & & & & \\
\hline & Aggresive & $\mathrm{X}$ & & & \\
\hline & Competitive & $\mathrm{X}$ & & & \\
\hline & Pride & $\mathrm{X}$ & & $\mathrm{X}$ & \\
\hline & Strong & $\mathrm{X}$ & & & \\
\hline \multirow{5}{*}{ Feminine } & Emotional & $\mathrm{X}$ & $\mathrm{X}$ & $\mathrm{X}$ & $\mathrm{X}$ \\
\hline & Graceful & $\mathrm{X}$ & & $\mathrm{X}$ & \\
\hline & Innocent & $\mathrm{X}$ & $\mathrm{X}$ & & \\
\hline & Weak & $\mathrm{X}$ & $\mathrm{X}$ & $\mathrm{X}$ & $\mathrm{X}$ \\
\hline & Deceitful & $\mathrm{X}$ & & $\mathrm{X}$ & $\mathrm{X}$ \\
\hline
\end{tabular}

\subsection{Hierarchy Men Over Women}

It is not always easy to find hierarchy because a narrative may pretend to narrate the only "true" reality (Boje, 2001). Gender relation always been in the shadow of power and domination. Man dominates women over their gender role. Hierarchy refer to category ranking where attribute being valued differently. Gender hierarchy is man's expression in dominating women and is illustration of collective or individual ego; as a member of "strong sex" group (N'Guessan, 2011). This hierarchy did not biologically constructed but culturally. Simone de Beauvoir assert that when human was born, man and women have the same right. Only then the society construct and differentiate this condition on the bases of gender hierarchy.

As the only woman, unavoidable, makes Masago become inferior in front of the collective power of man. Unsurprisingly, although become a victim, Masago always getting bad testimonies from those men. Especially Tajomaru and Takehiro, each of their testimonies support each other, despite the fact that Tajomaru raped his wife. Tajomaru praised Takehiro sword's skill "And he fought really well. We crossed swords over twenty-three times. Think of that! No one had ever crossed over twenty with me before. Then I killed him." or Takehiro's ally with Tajomaru against Masago that asks Tajomaru to kill him. This alliance try to legitimise men's supremacy, patriarchy, and hatred toward women, a camuflage attack toward women (Synott, 2003).

Sexism is social relation that degrade women (Humm, 2002). It's gender discrimination that usually deal with women's negative sentiment that came from belief that women are worthless or unable to do things compare to men as a practical way to make differentiation between both of them. Women always become subordination.

Verbal (name calling - shameless whore) and emotional (disgusted gaze) abusive, physical and sexual (rape) violence are aggressions manifestation that Masago have to face from Tajomaru and Takehiro. Males raping and harassing females is often more about power than about sex. Social relation between man and 
women is representation from capitalistic system (N'Guessan, 20110). Women become proletarian, helpless slave that can't change the situation.
1. The main reason in defining women as second class citizen under the man came from division work history where women doing unpaid job while men become the breadwinner, the master. Women maintained as subordinates to legitimise men's domination in the world.

Figure 1. Masago in despair in front of Tajomaru and Takehiro

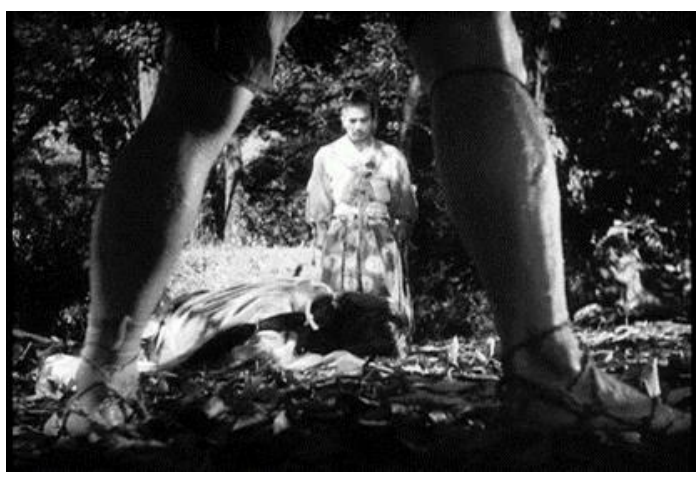

How men dominates women also being projected by it's visual storytelling. We can see it in picture above. From Woodcutter testimony, we found out how both of Tajomaru and Takehiro in seeing the lowly Masago. With facedown, Masago being put between both men with Tajomaru's feet as a foreground. This low angle shot being taken to emphasize the domination of men over women. Masago being seen as worthless human compared to the powerfull men.

Takehiro said to Masago "Don't waste your time in crying. No matter how hard you cry no one is going to be taken in by it". Takehiro wants to make it clear that Masago's cying wont budge Tajomaru and himself. Her tears even makes them look more powerfull compared to the weak, helpless Masago. Crying is seen as a mark that women being in her lowest point.

This hierarchy used hegemonic masculinity as the pattern of practice that allowed men's dominance over women to continue. The dominance of men and the subordination of women constitute a historical process, not a self-producing system (Connell, 2005).

\subsection{Questioning Masculinity}

"Women are equal to helpless man". This saying from Aristoteles (Synoott, 2003) show how women's position compared to men's masculinity is being mark with everything that did not fit with femininity. Rashomon is selfdeconstruct it's own hierarchy. The reversal of binary opposition will open up new analysis and let us think differently. Reinterpreting the hierarchy intent to see how the marginalize women can be the dominant concept, to give "voice" to them. Masago will be seen to have more control and power than the men.

Rashomon points out that tragedy in the forest actually happened because of Masago's beauty. If it's not because of a mild wind that blowing Masago's veil that disclose a glimpse of her charm, Tajomaru won't have the desire to have her, result in raping and murdering her husband. Tajomaru said "It was just a glimpse. First I saw her, then she was gone - I thought I had seen an angel. Then I decided I would take her, that I'd have her even if I had to kill the man."

Women's body is unrepresented power (Humm, 2002). For Theophrastus and Theokritus, beauty is a silent deception and crime in ivory jewerly. This saying reaffirmed in Orestes through the word of Elektra that blaming Helena as the cause of 
all the death in the war of Troya "Oh, how evil the beauty of human, corrote and destroy everything that has been touched" (Synott, 2003). Masago is Helena, in analogy. With his "power", she "succedd" to force Tajomaru to have her and Takehiro to risk his life, to death.

Reversal of hierarchy was not only about women have the domination over man, but also how men showing trait that usually have by women. Tajomaru and Takehiro were not always exhibiting what a men should do to become "a real man". Testimonies that tell them that way want to make sure that it's no matter man or woman, both of them are human that have weaknesess - and its not always be women's.

Crying and scare are identical with women's trait but Masago was not the only one that showing tears in Rashomon. Takehiro himself tell that he is the one who sobbing because his pride fall apart; his wife being raped and unfaithful to him. Masago even asks Tajomaru to kill him because she can't leave with Tajomaru if he still alive. Scenes that show Takehiro heartbroken tears did not overrated, different with Masago's scene of crying.

Slightly, what Takehiro testifies about himself will harm his manliness as a man and a Samurai. But some say that tears won't fade the masculinity away. This has been proved in 12th century's Japan epic novel entitled "The Heike Story". Heiki Kiyomori, a young commander in Japan middle era, cried because of spirituality matter and the death of his best friend. When Masago cried cause by misery, fear, and sadness, Takehiro cry because his pride and principle. The impression of crying became different because it has been practiced by different gender. This is happened because, generally men trained to do things that didn't require emotional, like: hunting, working, while women usually do more emotional things, like: giving birth, nurturing child.

Unfortunately, what Takehiro try to prove backfire when the Woodcutter testify against him. In his witness, Takehiro beg Tajomaru for mercy - a Samurai known for his fearleness of death kneel in front of bandit who try to take his life - 'I don't want to die! I don't want to die!". In Bushido code, a samurai can practice Seppuku (kill himself) if being ask for as punishment or voluntarily done by himself if he is in the hand of enemy. What Takehiro done really defying the rule of Samurai's spirit he should have afraid of death.

As a Bandit and a samurai husband, Tajomaru and Takehiro cowardly don't want to take a duel for Masago sake, a woodcutter testify. Masago mock them as weak men, when Tajomaru not sure enough to sacrifice his life to grab Masago from her husband and Takehiro not heroic enough to take revenge for what Tajomaru done to her wife. Both of them uncertain with what should they have done in that situation.

"It's not me, not me - it's you two who are weak. If you are my husband then why don't you kill this man? Then you can tell me to kill myself. That is what a real man would do. But you aren't a real man. That is why I was crying. I'm tired, tired of this farce. I thought that Tajomarn might find some way out. I thought that if he would only save me I would do anything for him. But he's not a man either. He's just like my busband! Just remember......that a woman loves only a real man."

Tajomaru and Takehiro can be afraid, weak, scare to get hurt too, just like what women usually be seen and this is the reason why Masago mock and ridicule them. Men are sensitive of insulting, especially from women (Fromm, 2007). A coward will be turn to a heroic if he being laugh by women. Fear of death is better than "fear" being humiliated by women and this is the heroic characteristic of men. The implication is a hatred legitimation toward women, a defensive function - dominating women, controlling them, make them weak and inferior. Because if men feared by women with threat of physical abuse, torturing, or death, women would be no longer be able to mocking and insulting men (Fromm, 2007). 
Figure 2. Tajomaru and Takehiro advancing uncertainly

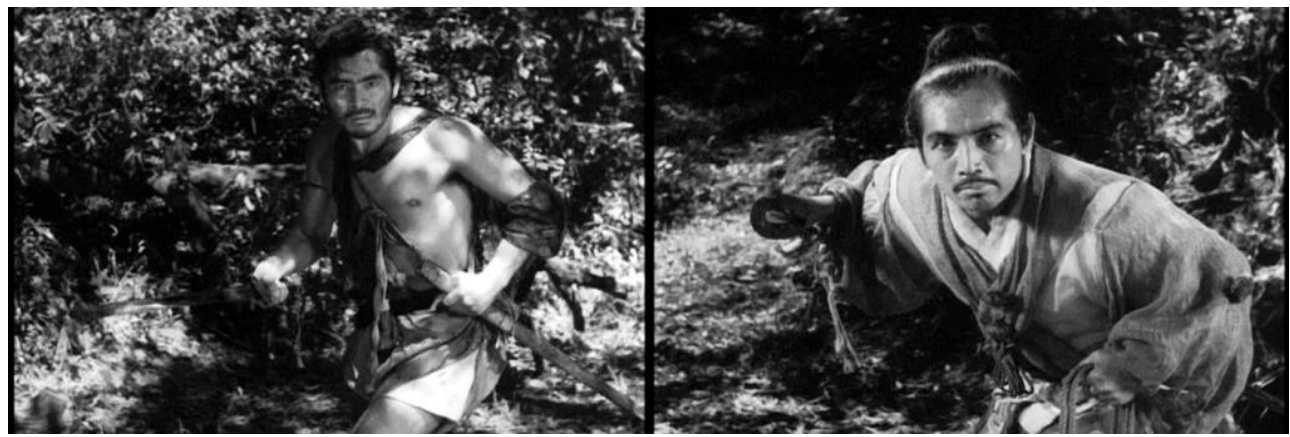

Derrida identifies the way in which feminism try to oppose West's binary opposition (1) Feminist try to took masculine characteristic, because there's no exact reason why men's characteristics are naturally theirs and (2) Feminist try to reverse the binary by priveledging women (Papadelos, 2006).

\subsection{The Silent of (Original) Rape}

Silenced voice become something to be considered in deconstucting narrative text. There are voices that do not included in the given story, is it purposeful or not for certain interest. Rashomon treat the raping, as one of the main crime, different with the death of the husband. Rape is a social problem that have long term negative physical and psychological consequences for the victim (Fanflik, 2007). Feminist define raping as an attitude and social institution that perpetuate patriarchy domination and based on violence, not just a crime (Humm, 2002). Besides Tajomaru's testimony, all other witness speaks nothing about the rape.

As a representation of women voice, we think that Masago's will become the one who give the description of originary crime. That expectation went in vain when in the courtyard she begin tell her story "..and then after having taken advantage of me..". Masago seem to ignorant about the misfortune that happened to her just like the men do. Sandra Wawrytko (Redfern, 2014) suggest that because her story begins after the rape, omitting any reference to it, her testimony, of necessity, comprises the facts filtered though the abiding pall of gender opperession. The absence of the rape from her testimony reinforces the social injustice that leaves her unavenged and the audience aware of her status: unequal and without recourse to judicial system (Redfern, 2014).

Takehiro, through medium, also recall memories after the rape, "The bandit, after attacking my wife, sat down beside her and tried to console her". What just happened to his wife never been of much account to him, so he think that it's not important to tell about the rape.

The before-rape voice never given a change to tell even from the victim. There is a rape, but we can't find a way to see the trace of it. This absence shows how the force of patriarchy priveledged the crime againt the husband over the committed against his wife.

Tajomaru's story, the male voice, become the only one that represent the before-rape event. Even in Tajomaru's version, it does not show the sexual violation and it simultaneously presents a visual transformation of the rape into a consensual sexual encounter and libidinal liberation (Redfern, 2014). So, it's just a glimpse of trace we can imagined about how the actual raping did really happened.

Clair (1998) discuss ways that people are silenced, one of them is that how the metaphors of voice and silence can contain each other (voice as silence and silence as voice). The absence of Masago's voice become Masago's voice to keep their private domain "we don't talk about that". Reading the silence between the 
lines is a way to deconstruct the forces that oppress (Boje, 2001).

Particularly, Redfern (2014) suggests that the linguistic intimations and visual hints, subtle yet omnipresent in the male narratives that seek to occlude the wife's and the crime against her in the face of a stifling phallocratic order that seeks not liberation but the status quo in which the male narratives are dominant. The absence of women's voice become the trace of men's power in surpressed women, even when she become the victim.

\section{Conclusion}

Rashomon is about relativity of truth, which testimonies is the honest one. We choose what we want to believe, which is influenced by external factors. Credibility and reliability of character as the determining factor to decide which one has the strongest argument to believe. Based on Fisher's narrative paradigm, narrative has to be rational. It should be coherence, character show continuity throughout their motives and actions. Gender become key factor that affect the construction of meaning in Rashomon.

The domination of men's voice disturbed the balance of narrative especially in describing Masago, the only women. The men form an ally cornering Masago by unanimously agreed that Masago is just typical weak, manipulative women they used to know. By contrast, they makes themselves, as a man, look superior, showing the glory of man. Raping as one of the crime being neglected to be considered important. Not only by Takehiro, but also Masago herself refused to speak about actual tragedy, because the acknowledge of rape as a crime will assault the phallocracy.

Beyond this findings, this study contributes to the general discussion on media and gender especially in generating new discourse about binary opposition men/women by questioning masculinity in movie. As a cultural effect, as a textual effect and as an effect in a phallocentric history of philosophy, gender is rendered by its internal instability (Deutscher, 1997) so there's nothing natural, objective, and scientific about all the gender pratice in society, particulary when gender intersect with cultural contex. Borrow Derrida's concept of phallogocentrism, Rashomon build the narrative by priviledging the masculine in the construction of meaning. Rashomon focusing on masculine point of view in seeing women (Masago), themselves, and the raping incident. Feminist narratology serves to clarifying the interpretation of narrative text that deal with gender-related matters.

With its narrative power, media being responsible for keeping and reinforce conservative culture about gender. Gender proved to be one of narrative strategy in playing the character code that universally accepted. Because narrative living in the society, so do gender. 


\section{Reference}

Beauvoir, S. d. (1953). The Second Sex. London: Lowe and Brydone.

Boje, D. M. (2001). Narrative Methods for Organizational \& Communication Research. London: Sage Publications.

Clair, R. P. (1997). Organizing silence: Silence as voice and voice as silence in the narrative exploration of the treaty of New Echota. Western Journal of Communication, 61(3), 315-337. https://doi.org/10.1080/1057031970 9374580

Connell, R. W. (2005). Hegemonic Masculinity: Rethinking the Concept. Gender \& Society, 19(6), 829-859. https://doi.org/10.1177/0891243205 278639

Deutscher, P. (1997). Yielding gender: feminism, deconstruction, and the history of philosophy. London; New York: Routledge.

Fisher, W. R. (1987). Human Communication as Narration : Toward A Philosopgy of Reason, Value, and Action. Columbia: University of South Carolina Press.

Fulton, H., Huisman, R., Murphet, J., \& Dunn, A. (2005). Narrative and Media. New York: Cambridge University Press.

Gauntlett, D. (2002). Media, gender, and identity: an introduction. London; New York: Routledge.

Herman, D. (Ed.). (2007). The Cambridge companion to narrative. Cambridge; New York: Cambridge University Press.
Humm, M. (2002). Ensiklopedia Feminisme. Yogyakarta: Fajar Pustaka Baru.

Kurosawa, A. (1950). Rashomon. Criterion.

Lacey, N. 2000. Narrative and Genre. New York: Palgrave.

Lofgren, E. R. (2015). The interstitial feminine and male dominance in Rashōmon. Journal of Japanese and Korean Cinema, 7(2), 113-132. https://doi.org/10.1080/17564905.20 15.1087146

Redfern, N. (2013). Film style and narration in Rashomon. Journal of Japanese and Korean Cinema, 5(1-2), 21-36. https://doi.org/10.1080/17564905.20 13.10820070

Sarup, M. (2011). Panduan Pengantar untuk Memahami Postrukturalisme dan Posmodernisme. Yogyakarta: JalaSutra.

Stern, Barbara B. (1996). Textual Analysis in Advertising Research: Construction and Deconstruction of Meanings. Journal of Advertising, 25(3), 61-73. Taylor \& Francis, Ltd.

Synnott, A. (2003). Tubuh Sosial: Simbolisme, Diri, dan Masyarakat. Yogyakarta: Adipura.

Tyree, T. (2011). African American Stereotypes in Reality Television. Howard Journal of Communications, 22(4), 394-413. https://doi.org/10.1080/10646175.20 11.617217

N'Guessan, K. G. (2011). Gender Hierarchy and The Social Construction of Feminity: The Imposed Mask. Acta Iassyensia Comparationis, 185. 
Volume 1, Number 1, April 2017; (51-62) 